www.jmscr.igmpublication.org Impact Factor (SJIF): 6.379 Index Copernicus Value: 71.58 ISSN (e)-2347-176x ISSN (p) 2455-0450 crossref DOI: https://dx.doi.org/10.18535/jmscr/v6i5.139

\title{
A Current Trend in the Scenario of Major Joint Disorder of Ayurveda PAKSHAGHATA (HEMIPLEGIA)
}

\author{
Author \\ Lilabati Mishra \\ Email: drlilabatimishra@gmail.com, Mobile: 7978259851
}

\section{Nidana}

Pakshaghat is considered as a Vatavyadhi by Brihat trayee and Laghu trayee. Kashyapa is the Laghu trayee. Kashyapa is the only authority mentioned it among the "Asheethi Vathika Rogas"

Sushrutha's Samprapthi narrates that there are associated doshas, but Vata is considered as the Principle dosha responsible for the consalion of the disease.

Specific causative factors are not stated for Pakshaghat. As such the general Vatavyadhi nidanas and Vata Prakopa karanas are to be considered as Nidan factors. However a specific Nidan has been mentioned for Pakshaghat is Kashay Ras Adhika Sevans

Difference gums responsible for Initiation of Vata

1. Ruksha

2. Laghu

3. Shetha

4. Khara

5. Vishade

6. Abhishyandi
Ahara and Vihar possessing the above said Gunas are the Vata Initiation. Vata Prakopa takes place during the below mentioned kalas i.e.

1. Raining Season

2. After Digestion

3. Balavadivigraha

4. Summer

5. Mid-Night

A few of the Vata Prakopa kara aharas which are in general uses are mentioned here under...

1. Mudga

2. Masoor

3. Adhaki

4. Chanaka

5. Tumbhi

6. Jambava

7. Rasamasha

8. Yava

9. Kanda

10. Alabu

11. Nimba

12. Udumbara

13. Sarshapa

14. Palandu 
As Kashayarasa Adhika Sevans is mentioned as the specific causative factor for Pakshaghat, The Kashayvarga Dravyas are also considered as nidanas...

1. Priyangu

2. Ananta

3. Amra

4. Amrasthi

5. Lodhar

6. Mocharas

7. Priyala

8. Badara

9. Saliki

10. Ashaka

11. Vibhitaka etc.

\section{Poorva Roopa}

The poorvaroopa are not mentioned specially for Pakshaghat. The Lakshna as which are seen partially or in completely can be considered as poorvaroopas for Pakshaghat...

Asthiparvabheda, Lomaharshana, Pralapa, Amidratha, Spandana, Moha, Ayasa. These are the Poorva Roopa.

\section{Roopa}

The signs and symptoms which are manifested specifically can be considered a Roopa.

1. Cheshtanivritti of a Praksha (Right or Left)

2. Vaksthambha

3. Sandhibandha vimokshana

4. Siru Snyu vishodhana

5. Dibaratra Shira, Padaparyantha ardhanga Shoola

\section{Types}

Pakshagata is of two types that pittasa and kaphasa.

Pittasa - Daha, Samthapa, Murcha

Kaphasa - Shaithya, Shotha, Gurutwa but Sushruta has mo+ mentiomed specifically. The amubomda closhas or the classification but while explaining about the Sadhyasadhyata categorised the disease into 3 varities, ego - 1. Sudha Vataja

2. Samrishta doshaja (Pitta 8khrills)

3. Dhatakshayoja

\section{Other Lakshanas of the disease}

1. Parvanam Samkocha, Hostha, Padr Sthamkh Asthi, Parvabheda, Peda, Prishtashirograha, ongasosha, Amidra, Spadana Gatrusupta, Spamlam, Maha etc.

\section{Upasaya}

Upasaya is one which is/are suitable to the patient and/or diseas, whether this may be ahara, aushada or vihar this can do has, when the Lokshamas are not giving the perfect knowledge of the disease, Upasayes must possess the opposite or more qualities of hetu and vyadhi.

\section{A few dravyas which are upasyas}

1. Patala, Lasuonas, Drdima dwaya Parushaka, Jambira, Nagara, madhuka parasarion, Rabu tailam, Payes, Noveemtail Ramata, moolaka etc.

\section{Somprapti}

Urdhwadeha dhamamis which are directed downwovels and Laterally are affected in pakshagata. Eigher dekshinei or varva Dumanis or Shisas are affected by extremely agnitated vata dosa.

\section{Upadrava}

Vata Vyadhi are included among ashtavridha maha gedas, | Vasically these disease are difficult to threat, if these areassociated with prama mamos Kshays, swasa, hikka, sosher, " Irishna, Jwara Murcha, atthisaca should mot be treated.

visarp, daha, ruk, sanga, murcha, arudhi agmimandya, mansa, balakshaya, hridroga, vidradhi are the upadravch.

\section{Arishta Lakshana}

The patient of dhatukshaya jamya vatavyadhi should be left untreated adhmana, achioypain, coliypain - a case of vatavyadhi developing these symptoms usually imedicate the umfavourable outcome. 


\section{Sodhyasadhyata}

Vata in its association with pitta or kapha is sadhya. In case of a recent conset, if the patient is strong amough to suftain the disease process and without any upadravas eidicate good prognosis.

Usually the disease due to vataprakopa are grave emough when occurs to a vata prakritthi person, As the disease is rehated to madhyama rogo marga and trimarmas, The progmosis is bad, it may be yopyaor asodhya, but it can be treated with great difficult if it is of recemtomest.

If vata alome is envolved without any doshanu bandhatha, it become krichrasadhi.

Dhatrikshya janya pakshagata is asadhya to treat, if the patient is either grabhini. Suthika, bala, vriddha, Ksheena, asrik, loss of blood and einsensitive also indicate unfavourable out - come.

\section{Pakshagata Chikitsa}

Among the various vatabyodhis pakshagata is avery complicated disease. The cause for this complicated nature is due to the einvolvement of the pranayathana and marma that Siras, Sirus is a place in which many marmas and indriyas are situated.

These is an evdution in the chikitsa pattern for Charak Samhitha to Sushruta Samhitha. The treatment mentioned in charak Samhitha is somewhat simple when compared to Sushruta, different methods of Sushruta, Different methods of treatment patterns are stated below.

\section{Snehanam}

2. Swedanam

3. Virechanin

\section{Snehanam}

If can be done with chaturvidha sneha and also with Eramdu Tail. Eramosa tail is having all the three actions i.e. Snehana, Swedana and virechana and even it is indicated in Pakshagata also, it can be used even if the disease is associated with pitta, kapha and rakta or in case of vata avaranas.

\section{Swedanam}

Sarvadhik swedh is very essential to bring the doshas from all the dhatus in to the koshta, It is not possible to do swedan to the urdhwadhe i.e. Sirus as it is a marm and pranayathama, Hence it become difficult to bring the sthanasamsritha doshas from the cirus into the koshta.

Shashtika Shali pinda sweda, Baluka sweda, or parishek sweda is well suited, any snigdha sweda can be performed to the patient.

\section{Virechana}

Irivrit or Satphala Siddha ghrita can be used Eramda tial can also be used as specific drug by changing the different anupanas hike ksheera, gomutra, Yusha, triphala kwatti etc.

After the completion of swedan, swedans, anuvasana vasti is the next treatment to be adopted, if performed with pitta kapha hara dravyas it can used in the dosha anulamdhata

\section{Chamanachikitsa}

1. Musha, Atmagupta, Eranda, Hingu Saindavam - Kwatha

2. Atmagupta - Balamasha, Visura, Erandu Saindava - Kwatha.

3. Mashu, Bela, Sukasimbi, Katruma, RAsna, Urvbuka, Ashwagandha, Ramata Lavana- kwatha, Indicated in Pakshagata.

4. Mosha, Hingu, Saindava, Gramthika, Agni, Kanashumti, Rasna, Sainduva, Mosha KwathaTaila preparation.

5. Bhringarasa, Nirgumoli, Matsyakshi, Arkapatra, Tail, Maricha - Nasya Prayoga

\begin{tabular}{|l|c|c|c|c|}
\hline S.No. & Name of Yoga & Dosage & Anupana & Days \\
\hline 1 & Brihat Vata Chintamani twine & $125-250 \mathrm{mg}$ & Balarista 20ml & 15 days \\
\hline 2 & Ekamgaveer ras twine & $125-250 \mathrm{mg}$ twine & Milk & 15 days \\
\hline 3 & Xogemdra dosa & $125-250 \mathrm{mg}$ & Dashamula Kwatha 20ml & 15 days \\
\hline 4 & Trayodoshanga Guggul & $250-500 \mathrm{mg}$ twice & Rasmadi Kwatha 20ml & 30 days \\
\hline 5 & Mahavata Bedwansini & $125-250 \mathrm{mg}$ twice & Aswagandha rista 20ml & 30 days \\
\hline
\end{tabular}


1st Stage -

Morning -

Akangovir Rasa 250 - 250mg

Vicamabhamla 125 - $125 \mathrm{mg}$

Brmhirasayan 25 - 20gm

afterfood -

A jomedad churna 3 - 3gm

Aswagandharista $25-25 \mathrm{ml}$

Night - Dashamuladyoghrat 20 G. with ghita.

7am massage - Mahamasha Tail 40 Minutes

2st Stage -

Morning - Yogemdraras - 125 - 125gm with honey

Trayodesagga guggul - 2 - 2gm

Mahakaladi Kwatha $20-20 \mathrm{gm}$

Afterfood - Sunthechurna 1gm with warm water.

Dasamularista - 25 - 25ml

Day 2pm - Mahayogaraja guggul - 2gm with warm water.

Night - Eramda Sneha 10gm with milk.

3rd Stage -

Morning -

Brihat vata chintamani 125 -

$125 \mathrm{mg}$ with Triphala Kwatha.

Muktasakti 250 - 250mg.

Dashemula Kwatha - 15 - 15ml

Afternoon - Chinhnada guggul - 2 tab with warm water.

Night - Mahenarayanatial $15 \mathrm{ml}$ with milk

\section{Other Medicines}

Erandapaka, Bhalatakpaka, Bhartatak - Lalehe, Aswagandapakaeto.

\section{The fiver in the Pakshaghata}

Morning - Brihata latagogamkusa Ras- 250mg with Pamarasa8huony

Afternoon - BhulaneswarRas + Basrukyar with warm water

Evening - Vatamisumdanarasa + Basrukyar with warm water.

Night - Byasamarchurnna 3 gm with warm water, this times lath less.

\section{Stage of Prameha}

Morning - BrihatabongeswarRasa with honey

Evening - BasamtakusumakaraRasa syasus with satahar it honey.

Night - Surihadi Salica is $\mathrm{ml}$ with cooled water.

\section{Stage of Bahumutra}

Morning - BasantakusutakarRasa 120mg with Banana flower syozasa.

Afternoon -Dasamularista $15 \mathrm{ml}$ with cold wated. Evening - Brihatahatachintamani Rose 125mg with honey + water.

Morning \& Evening massage Madhyana Narayana Tail.

\section{Harhal Drug \& Chikitsa}

1 .

\section{Refermoes}

1. Charaka Samhita Vimana Stana \& Chikitsastana \& Chukrapani Commentary.

2. Sushrutha Samhita Sutra Stana \& Nidana Starm.

3. Yoga Ratnakara.

4. A shanga Somgraha Sarira Stana.

5. Bhava Prakasha Madhyama Khomda.

6. Ayurveda Chikitsa Vigyan Vatalyadlni.

7. The principles and praltice of Kayachikitsa (Dr. S. Suresh Babu)

8. Pancharma Ayurveda Chikitsa Vigyana

9. Vatalyadhi (Krushtachamlra Tripatty)

10. Shahashra smzuti \& Anuthuti (Rames Das) 